\title{
ANALISIS BUTIR SOAL DAN KEMAMPUAN SISWA MENJAWAB TES UN DAN UAS GANJIL MATA PELAJARAN BIOLOGI KELAS XI SMAN/MAN DI KOTA MEDAN
}

\author{
Siti Salmah Lubis ${ }^{1}$, Syarifuddin1, Herawati Dongoran ${ }^{2}$ \\ ${ }^{1}$ Program Studi Pendidikan Biologi, FMIPA, Universitas Negeri Medan JI. Williem Iskandar Psr. V Medan Estate, \\ Medan, Indonesia, 20221 \\ ${ }^{2}$ MAN 1 Medan, Jl. Williem Iskandar Medan \\ E-mail : sitisalmahlubis@gmail.com
}

\begin{abstract}
ABSTRAK
Penelitian ini bertujuan untuk mengetahui kemampuan siswa menjawab soal UN dan UAS serta mengetahuii kualitas soal UN materi kelas XI Semester Ganjil Tahun 2012 - 2016 dan UAS Ganjil T.P 2016/2017 berdasarkan uji coba yang dilihat dari aspek kognitif berdasarkan Taksonomi Bloom, Tingkat Kesukaran, Daya Pembeda, dan Reliabilitas. Metode dalam penelitian ini menggunakan metode deskriptif kuantitatif. Sampel uji coba soal adalah 6 kelas XI MIA berjumlah 238 siswa dengan teknik cluster sample.. Objek penelitian adalah soal UN materi kelas XI Semester Ganjil Tahun 2012-2016 dan soal UAS yang berasal dari 6 sekolah. Hasil penelitian menunjukkan bahwa siswa lebih mampu menjawab soal UN dibandingkan dengan UAS berdasarkan nilai rata-rata siswa dalam menjawab soal UAS Ganjil lebih tinggi dibandingkan soal UN. Berdasarkan aspek kognitif taksonomi Bloom sebaran soal UAS Ganjil T.P 2016/2017 belum memenuhi proporsi soal yang seimbang berdasarkan formulasi C1 40\% C2 20\% C3 20\% C4 10\% C5 5\% C6 5\%. Berdasarkan tingkat kesukaran sebaran soal UN dan UAS Ganjil T.P 2016/2017 belum memenuhi kriteria soal yang seimbang berdasarkan formulasi sukar $25 \%$ sedang $50 \%$ dan mudah 25\%. Berdasarkan daya pembeda sebaran soal UN dan UAS T.P 2016/2017 belum memenuhi kriteria soal yang baik yaitu dengan kriteria daya pembeda $0,30-1,00 \geq 85 \%$. Kriteria daya pembeda 0,30-1,00 pada soal UN 32\%, UAS MAN 1 Medan 36\%, UAS MAN 2 Model Medan 53\%, UAS SMAN 4 Medan 52\%, UAS SMAN 9 Medan 35\%, UAS SMAN 11 Medan 49\%, UAS SMAN 18 Medan 23\%. Berdasarkan reliabilitas, soal UN memiliki reliabilitas rendah $(0,3)$ sedangkan soal UAS rata-rata memiliki reliabilitas tinggi $(0,60-0,79)$.
\end{abstract}

Kata Kunci: Analisis, butir soal, Ujian Nasional, Ujian Akhir Semester

\section{ABSTRACT}

The research aims to determine the ability of students to answer of National Exam question's and Odd Semester Exams questions as well as to know the quality of National Exams Class XI Odd Semester Year 2012 - 2016 and Odd Semester Exams academic year 2016/2017 based on experiments viewed from the cognitive aspects based on bloom's taxonomy, level of difficultness, distinguishing power, and reliability. The method in this research using quantitative descriptive method. Sample test question is 6 class XI MIA amounted to 238 students with cluster sample technique.. The object of research is a matter of National Exams Class XI Odd Semester Year 20122016 and about UAS coming from 6 schools. The results showed that students are better able to answer the National Exams question's compared with Odd Semester Exams based on the average score of students in answering Odd Semester Exams question's is higher than the National Exams question. Based on the cognitive aspects of Bloom's taxonomy the distribution of Odd Semester Exams academic year 2016/2017 does not meet the proportion of balanced questions based on formulation C1 40\% C2 20\% C3 20\% C4 10\% C5 5\% C6 5\%. Based on the difficulties of the distribution of UN and UAS Problems Ganjil T.P 2016/2017 does not meet the criteria of a balanced question based on a difficult formulation $25 \%$ medium $50 \%$ and easy $25 \%$. Based on the distinguishing power of the distribution of the question of National Exam and Odd Semester Exams academic year 2016/2017 not meet the criteria of a good question with the criterion of differentiating power $0,30-1,00 \geq 85 \%$. Criteria of differentiating power 0,30 - 1,00 on question's of National Exams 32\%, Odd Semester Exams of MAN 1 Medan 36\%, MAN 2 Medan Model 53\%, SMAN 4 Medan 52\%, SMAN 9 Medan 35\%, SMAN 11 Medan 49 \%, SMAN 18 Medan 23\%. Based on the reliability, the problem of National Exams has low reliability (0.3) while the average Odd Semester Exams has high reliability (0.60-0.79).

Keywords : Analysis, item test, National Exam, Odd Semester Exam 
JURNAL PELITA PENDIDIKAN VOL. 5 NO. 3

Lubis, SS., Syarifuddin., Dongoran, H.

Halaman : $318-325$
pISSN : 2338 - 3003

elSSN : 2502 - 3217

\section{PENDAHULUAN}

Evaluasi adalah kegiatan yang terencana untuk mengetahui keadaan suatu objek dengan menggunakan instrument dan membandingkan hasilnya dengan tolak ukur untuk memperoleh kesimpulan. Menurut Silverius dalam Fathurrohman \& Sutikno (2007), menjelaskan evaluasi yang baik haruslah didasarkan pada tujuan pembelajaran (instructional) yang ditetapkan oleh pendidik dan kemudian benar-benar diusahakan pencapaiannya oleh pendidik dan peserta didik. Pada umumnya ada dua teknik evaluasi yaitu dengan menggunakan tes dan non tes.

Alat evaluasi yang sering digunakan dalam proses belajar mengajar adalah tes. Tes merupakan alat atau prosedur yang digunakan untuk mengetahui atau mengukur sesuatu dengan cara atau aturan-aturan yang sudah ditentukan. Sebagai alat ukur, tes harus benar-benar mengukur hasil belajar dengan sebaik-baiknya sehingga dalam penggunaannya akan menghasilkan pengukuran yang objektif. Tes sebagai alat ukur perlu dirancang secara khusus sesuai dengan tujuan pembelajaran dan perlu disiapkan dengan sebaik-baiknya sesuai dengan kaidah-kaidah dalam penyusunannya. Dalam suatu proses pengukuran sangat diperlukan tes dengan kualitas yang baik, sebab baik buruknya kualitas tes akan menentukan kualitas data yang dihasilkan.

Salah satu tes yang disusun oleh guru dalam mengevaluasi siswa adalah tes Ujian Semester. Pada setiap akhir semester siswa akan melaksanakan ujian sekolah, dimana soal-soal yang digunakan dalam ujian sekolah dibuat oleh guru bidang studi itu sendiri. Soal yang dominan digunakan dalam ujian sekolah adalah soal objektif, terutama pilihan ganda (multiple choice) karena soal pilihan ganda dapat mewakili lebih banyak materi, ekonomis dan efisien, serta memudahkan penilaian oleh guru. Berdasarkan pengamatan awal dan wawancara dengan beberapa guru di SMA/MA Negeri di kota Medan sedikit dari guru yang melakukan analisis awal untuk mengetahui kualitas soal ujian dikarenakan keterbatasan waktu. Selain itu instrumen penilaian yang digunakan guru untuk menguji hasil belajar peserta didik biasanya diambil dari berbagai buku atau kumpulan soal-soal ujian.

Dalam penilaian tingkat Nasional, Indonesia melaksanakan tes Ujian Nasional (UN). Ujian Nasional adalah penilaian hasil belajar oleh pemerintah yang bertujuan untuk menilai pencapaian kompetensi lulusan secara Nasional pada mata pelajaran tertentu dalam kelompok ilmu pengetahuan dan teknologi. Banyak siswa yang ketika diuji coba mengerjakan soal Ujian Nasional khususnya bidang studi Biologi menunjukkan nilai yang sangat rendah. Menurut observasi pada bimbingan belajar Adzkia didapatkan hasil Try Out Ujian Nasional T.P 2016/2017 di beberapa sekolah, ternyata nilai rata-rata untuk bidang studi Biologi adalah 3,44 3,96 4,82 dan 6,25 dari empat sekolah yang berbeda.

Berdasarkan nilai rata-rata Try Out Ujian Nasional untuk bidang studi Biologi dari empat sekolah tersebut, maka kemampuan siswa dalam menjawab soal Ujian Nasional masih dikategorikan kurang dan cukup. Sesuai dengan kriteria pencapaian kompetensi lulusan hasil Ujian Nasional jika nilai kurang dari atau sama dengan 55 masuk dalam kategori kurang sedangkan jika nilai 55 sampai 70 masuk dalam kategori cukup.

Karena itu peneliti ingin mengetahui apakah rendahnya nilai siswa berdasarkan Try Out Ujian Nasional dikarenakan tingkat kesulitan soal-soal ujian sekolah yang diberikan kepada siswa setiap akhir semester lebih rendah kualitasnya dibanding soal-soal Ujian Nasional. Kualitas butir soal dapat diketahui dengan melakukan analisis butir soal.

Dengan membuat analisis butir soal, setidaknya kita dapat mengetahui hal penting yang dapat diperoleh dari tiap soal, diantaranya sampai dimana tingkat atau taraf kesukaran soal itu, apakah soal itu mempunyai daya pembeda, apakah soal yang disusun reliable, dan bagaimana persentase aspek kognitif menurut taksonomi Bloom dari keseluruhan soal yang disusun. Berdasarkan uraian diatas maka peneliti tertarik untuk melakukan penelitian dengan judul "Analisis Butir Soal dan Kemampuan Siswa Menjawab Tes UN Dan UAS Ganjil Mata Pelajaran Biologi Kelas XI SMAN/MAN Di Kota Medan"

\section{METODE PENELITIAN}

Penelitian uji coba soal dilakukan di Madrasah Aliyah Negeri 1 Medan (MAN 1 Medan). Waktu penelitian dilakukan dari bulan Maret sampai dengan Mei 2017. Populasi sumber soal Ujian Nasional adalah soal Ujian Nasional yang telah disusun berdasarkan 5 tahun kebelakang. Populasi sumber soal Ujian Akhir Semester Ganjil T.P 2016/2017 dalam penelitian ini adalah seluruh 
JURNAL PELITA PENDIDIKAN VOL. 5 NO. 3

Lubis, SS., Syarifuddin., Dongoran, H.

Halaman : $318-325$

sekolah SMAN dan MAN yang sudah memiliki Akreditasi A di kota Medan. Populasi siswa yang dijadikan uji coba Soal adalah delapan kelas XI MIA di MAN 1 Medan, karena dari sekian banyak sekolah yang ditanyai kesediaannya, hanya sekolah MAN 1 Medan yang siswanya bersedia diuji coba. Sampel sumber soal Ujian Nasional adalah soal UN materi kelas XI Semester Ganjil Tahun 2012-2016 dengan menggunakan teknik purposive sampling dan sampel sumber soal Ujian Akhir Semester Ganjil T.P 2016/2017 dalam penelitian ini adalah enam jenis soal dari enam sekolah yang berbeda diantaranya empat soal diambil dari SMAN dan dua soal diambil dari MAN di kota Medan dengan menggunakan teknik acak penuh. Soal Ujian Nasional yang diambil berdasarkan 5 tahun kebelakang berjumlah 22 butir soal. Soal Ujian Akhir Semester Ganjil T.P 2016/2017 yang diambil dari keenam sekolah adalah soal bentuk pilihan berganda dengan jumlah soal masingmasing 25 butir soal dari MAN 1 Medan, 30 butir soal dari MAN 2 Model Medan, 35 butir soal dari SMAN 4 Medan, 20 butir soal dari SMAN 9 Medan, 35 butir soal dari SMAN 11 Medan, dan 35 butir soal dari SMAN 18 Medan. Jadi sampel sumber soal Ujian Akhir Semester Ganjil adalah soal pilihan berganda diambil dari enam sekolah yaitu MAN 1 Medan, MAN 2 Model Medan, SMAN 4 Medan, SMAN 9 Medan, SMAN 11 Medan, dan SMAN 18 Medan.

Sampel kelas untuk uji coba Soal Ujian Nasional dan Soal Ujian Akhir Semester Ganjil dalam penelitian ini adalah enam kelas dari delapan kelas MIA (Matematika Ilmu Alam) yang sama yaitu XI MIA-1, XI MIA-2, XI MIA-3 dan XI MIA-4, XI-MIA-5 dan XI-MIA-6 dengan mengunakan Sampel Kelompok atau Cluster Sample.

Penelitian ini merupakan jenis penelitian deskriptif kuantitatif. Artinya penelitian ini hanya untuk memaparkan gambaran konkret tentang kemampuan siswa menjawab soal Ujian Nasional dan Ujian Akhir Semester Ganjil serta kualitas butir soal Ujian Nasional dan Ujian Semester Ganjil yang meliputi analisis ranah kognitif berdasarkan Taksonomi Bloom, analisis reliabilitas, analisis tingkat kesukaran dan analisis daya pembeda berdasarkan uji coba.

Teknik analisis data terhadap butir soal UN dan UAS dengan menggunakan teknik analisis deskriptip kuantitatif. Kemampuan siswa menjawab soal diketahui berdasarkan nilai rata-rata. Tingkatan ranah kognitif Taksonomi Bloom pada soal dikelompokkan dan dibandingkan dengan kriteria
pISSN : $2338-3003$

elSSN : 2502 - 3217

soal yang baik yaitu dengan formulasi perbandingan C1 40\%, C2 20\%, C3 20\%, C4 10\%, C5 5\% dan C6 $5 \%$ Analisis butir soal diketahui berdasarkan rumus. Tingkat kesukaran $\left(\mathrm{P}=\frac{B}{\mathrm{~J} S}\right)$ Daya Pembeda $\left(\mathrm{D}=\frac{B_{\mathrm{A}}}{J_{\mathrm{a}}}\right.$ $\left.\frac{B_{B}}{J_{B}}=P_{A}-P_{B}\right)$ Reliabilitas $r_{11}=\left(\frac{k}{k-1}\right)\left(\frac{s^{2}-\sum p q}{s^{2}}\right)$.

\section{HASIL PENELITIAN}

\section{Kemampuan siswa menjawab Soal UN dan UAS}

Berdasarkan hasil uji coba dalam menjawab soal UN materi kelas XI Semester Ganjil Tahun 2012 - 2016 dan Soal UAS Ganjil T.P 2016/2017 diketahui rata-rata siswa lebih mampu menjawab soal UAS Ganjil dibandingkan dengan soal UN.

Berdasarkan hasil perhitungan diketahui nilai rata-rata siswa dalam menjawab soal UN dan UAS Ganjil T.P 2016/2017 pada kelas XI MIA-1 untuk soal UN 51,0 sedangkan soal UAS yang berasal dari SMAN 9 Medan 68,3. Kelas XI MIA-2 untuk soal UN 33,9 sedangkan soal UAS yang berasal dari SMAN 11 46,8. Kelas XI MIA-3 untuk soal UN 40,0 sedangkan soal UAS yang berasal dari MAN 1 Medan 64,0. Kelas XI MIA-4 untuk soal UN 37,3 sedangkan soal UAS yang berasal dari SMAN 4 Medan 56,7. Kelas XI MIA 5 untuk soal UN 36,0 sedangkan soal UAS yang berasal dari MAN 2 Model Medan 59,5. Kelas XI MIA-6 untuk soal UN 43,0 sedangkan soal UAS yang berasal dari SMAN 18 Medan 41,8.

Sebagian besar nilai rata-rata siswa dalam menjawab soal UN lebih rendah dibandingkan dengan soal UAS kecuali siswa kelas XI MIA-6 yang memiliki nilai UN lebih tinggi dibandingkan dengan nilai UAS dimana soal UAS berasal dari SMAN 18 Medan. Jadi dapat disimpulkan bahwa berdasarkan nilai rata-rata sebagain besar siswa lebih mampu menjawab soal UAS Ganjil dibandingkan dengan soal UN.

Dengan demikian, siswa mengalami kesulitan dalam menjawab soal UN dibandingkan dengan soal UAS Ganjil. Berdasarkan hal tersebut perlu diketahui bagaimana kualitas soal UN dan UAS Ganjil, kualitas butir soal dapat diketahui dengan melakukan analisis soal yang meliputi aspek kognitif soal berdasarkan Taksonomi Bloom, tingkat kesukaran, daya pembeda, dan reliabilitas.

Analisis Pengelompokan Soal Berdasarkan Aspek Kognitif Taksonomi Bloom 
JURNAL PELITA PENDIDIKAN VOL. 5 NO. 3

Lubis, SS., Syarifuddin., Dongoran, $\mathrm{H}$.

Halaman : $318-325$

Berdasarkan tabel kata kerja operasional maka soal UAS Ganjil T.P 2016/2017 yang didapat dari 6 sekolah diketahui sebaran soal berdasarkan ranah kognitif Taksonomi Bloom belum merata karena belum sesuai dengan proporsi soal yang seimbang C1 (40\%) C2 (20\%) C3 (20\%) C4 (10\%) C5 (5\%) dan C6 (5\%).

Berdasarkan hasil perhitungan, rata-rata distribusi sebaran soal ranah kognitif berdasarkan Taksonomi Bloom Soal UAS MAN 1 Medan pada C1 sebesar 32\% C2 sebesar 40\% C3 sebesar 24\% C4 sebesar 24\% C5 sebesar 0\% dan C6 sebesar 0\%, MAN 2 Model Medan pada C1 sebesar 37\% C2 sebesar $50 \%$ C3 sebesar 3\% C4 sebesar 10\% C5 sebesar 0\% dan $\mathrm{C} 6$ sebesar 0\%, SMAN 4 Medan pada C1 sebesar 26\% C2 sebesar $46 \%$ C3 sebesar 20\% C4 sebesar $8 \%$ C5 sebesar 0\% dan C6 sebesar 0\%, SMAN 9 Medan pada C1 sebesar $45 \%$ C2 sebesar 25\% C3 sebesar 20\% C4 sebesar 5\% C5 sebesar 5\% dan C6 sebesar 0\%, SMAN 11 Medan pada C1 sebesar 46\% C2 sebesar 26\% C3 sebesar 23\% C4 sebesar 5\% C5 sebesar 0\% dan C6 sebesar 0\%, SMAN 18 Medan pada C1 sebesar 31\% C2 sebesar 49\% C3 sebesar $11 \%$ C4 sebesar 9\% C5 sebesar 0\% dan C6 sebesar $0 \%$.

Sebaran soal ranah kognitif Taksonomi Bloom pada soal UAS MAN 1 Medan, MAN 2 Model Medan, SMAN 4 Medan dan SMAN 18 Medan didominasi oleh soal ranah kognitif C2 (memahami) sedangkan pada soal UAS SMAN 9 Medan dan SMAN 11 Medan didominasi oleh soal ranah kognitif C1 (mengingat).

\section{Analisis Tingkat Kesukaran Soal UN dan UAS Ganjil}

Berdasarkan hasil uji coba serta perhitungan mengenai indeks tingkat kesukaran soal, diperoleh indeks untuk soal UN materi kelas XI Semester Ganjil Tahun 2012-2016 dan Soal UAS Ganjil T.P 2016/2017 yang didapat dari 6 sekolah memiliki sebaran kriteria tingkat kesukaran dengan persentase belum memenuhi proporsi tingkat kesukaran soal yang seimbang yaitu $25 \%$ sukar $50 \%$ sedang dan $25 \%$ mudah.

Berdasarkan hasil perhitungan Soal UN dan UAS Ganjil yang berasal dari MAN 2 Model Medan, SMAN 4 Medan, dan SMAN 11 Medan didominasi oleh tingkat kesukaran soal kategori sedang. Secara berurut tingkat kesukaran soal dari persentase tertinggi sampai terendah pada soal UN adalah soal kategori sedang (82\%) sukar (14\%) dan mudah (4\%), MAN 2 Model Medan soal kategori sedang (53\%) mudah (33\%) dan sukar (14\%), SMAN 4 Medan soal
pISSN : $2338-3003$

elSSN : 2502 - 3217 kategori sedang (54\%) mudah (32\%) dan sukar (14\%), dan SMAN 11 Medan soal kategori sedang (69\%) sukar (20\%), dan mudah (11\%). Pada soal UAS Ganjil yang berasal dari MAN 1 Medan dan SMAN 9 Medan didominasi oleh tingkat kesukaran soal kategori mudah. Secara berurut tingkat kesukaran soal dari persentase tertinggi sampai terendah pada soal MAN 1 Medan soal kategori mudah (48\%) sedang (36\%) dan sukar (16\%), SMAN 9 Medan soal kategori mudah (65\%) sukar (20\%) dan sedang (15\%). Dan soal UAS Ganjil yang berasal dari SMAN 18 Medan tingkat kesukaran soal kategori sukar dan sedang hampir seimbang yaitu dengan persentase soal kategori sedang (46\%), sukar (43\%), mudah (11\%).

\section{Analisis Daya Pembeda Soal UN dan UAS Ganjil}

Berdasarkan hasil uji coba serta perhitungan mengenai indeks daya pembeda soal, diperoleh indeks untuk soal UN materi kelas XI Semester Ganjil Tahun 2012-2016 dan Soal UAS Ganjil T.P 2016/2017 yang didapat dari 6 sekolah memiliki kriteria sebaran daya pembeda yang belum memenuhi kriteria soal yang baik yaitu dengan indeks daya pembeda $0,30-1,00 \geq 85 \%$.

Soal UN dan UAS Ganjil yang berasal dari MAN 2 Model Medan dan SMAN 11 Medan didominasi oleh daya pembeda soal kategori cukup. Secara berurut daya pembeda soal dari persentase tertinggi sampai terendah pada soal UN adalah soal kategori cukup $(54 \% \%)$ jelek (32\%) tidak baik $(9 \%)$ baik (5\%) dan sangat baik (0\%), MAN 2 Model Medan soal kategori cukup (54\%) jelek (23\%) baik (13\%) tidak baik (10\%) dan sangat baik (0\%), SMAN 11 Medan soal kategori cukup ( $43 \%)$ jelek (34\%) baik (14\%) tidak baik (9\%) dan sangat baik (0\%). Pada soal UAS Ganjil yang berasal dari MAN 1 Medan, SMAN 9 Medan dan SMAN 18 Medan didominasi oleh daya pembeda soal kategori jelek. Secara berurut daya pembeda soal dari persentase tertinggi sampai terendah pada soal MAN 1 Medan adalah soal kategori jelek ( $40 \%$ ) cukup (24\%) baik (20\%) tidak baik (16\%) dan sangat baik (0\%), SMAN 9 Medan soal kategori jelek (50\%) cukup (30\%) baik $(10 \%)$ tidak baik (10\%) dan sangat baik (0\%), SMAN 18 Medan soal kategori jelek (57\%) cukup (17\%) tidak baik (14\%) baik (12\%) dan sangat baik (0\%). Dan soal UAS Ganjil yang berasal dari SMAN 4 Medan daya pembeda soal kategori cukup dan baik hampir seimbang yaitu dengan persentase soal kategori 
cukup (37\%) baik (34\%) jelek (14\%) tidak baik (12\%) dan sangat baik (3\%).

\section{Analisis Reliabilitas Soal UN dan UAS Ganjil}

Berdasarkan hasil uji coba serta perhitungan mengenai indeks reliabilitas pada soal UN dan UAS Ganjil diperoleh indeks untuk soal UN materi kelas XI
Semester Ganjil Tahun 2012-2016 tergolong rendah dan Soal UAS Ganjil T.P 2016/2017 dari 6 sekolah rata-rata memiliki indeks reliabilitas tinggi. Indeks reliabilitas dari setiap jenis soal dapat dilihat pada tabel berikut.

Tabel 1. Analisis Reliabilitas Soal UN dan UAS Ganjil T.P 2016/2017

\begin{tabular}{lcc}
\hline Jenis Soal & Nilai & Kriteria \\
\hline Ujian Nasional & 0,30 & Rendah \\
\hline Ujian Semester & & Tinggi \\
MAN 1 Medan & 0,72 & Tinggi \\
MAN 2 Medan & 0,78 & Sangat reliabel \\
SMAN 4 Medan & 0,89 & Sedang \\
SMAN 9 Medan & 0,56 & Tinggi \\
SMAN 11 Medan & 0,80 & Sedang \\
SMAN 18 Medan & 0,53 & \\
\hline
\end{tabular}

Dari tabel diatas, indeks reliabilitas tertinggi adalah soal Ujian Semester pada Soal yang berasal dari SMAN 4 sebesar 0,89 (sangat reliable), dan indeks reliabilitas terendah adalah soal Ujian Nasional sebesar 0,3 (rendah).

\section{PEMBAHASAN}

\section{Kemampuan Siswa Menjawab Soal UN dan UAS}

Dari hasil penelitian dalam menjawab soal UN dan UAS Ganjil T.P 2016/2017 kepada 238 responden ternyata siswa lebih mampu menjawab soal UAS yang berasal dari MAN 1 Medan, MAN 2 Model Medan, SMAN 4 Medan, SMAN 9 Medan dan SMAN 11 Medan dibandingkan dengan soal UN karena nilai rata-rata siswa dalam menjawab soal UAS lebih tinggi dibandingkan dengan soal UN. Namun sebaliknya nilai rata-rata siswa dalam menjawab soal UAS Ganjil yang berasal dari SMAN 18 Medan lebih rendah dibandingkan dengan soal UN, hal ini menunjukkan bahwa siswa lebih mampu menjawab soal UN dibandingkan dengan soal UAS yang berasal dari SMAN 18 Medan. Hal tersebut dapat dipengaruhi oleh tingkat kesukaran soal UN dan UAS Ganjil T.P 2016/2017 yang diberikan kepada siswa. Berdasarkan analisis yang telah dilakukan persentase tingkat kesukaran soal UN kategori mudah lebih rendah dibandingkan dengan soal UAS Ganjil dimana soal UN (4\%) MAN 1 Medan (48\%) MAN 2 Model Medan (33\%) SMAN 4 Medan (32\%) SMAN 9 Medan (65\%) SMAN 11 Medan (11\%) dan SMAN 18 Medan (11\%) hal tersebut menjadi alasan bahwa siswa lebih mampu menjawab soal UAS dibandingkan dengan soal UN khususnya soal UAS Ganjil yang berasal dari MAN 1 Medan, MAN 2 Model Medan, SMAN 4 Medan, SMAN 9 Medan dan SMAN 11 Medan karena soal UAS lebih mudah dibandingkan dengan soal UN. Namun pada soal UAS Ganjil yang berasal dari SMAN 18 Medan, tingkat kesukaran soal kategori sukar memiliki persentase yang jauh lebih tinggi dibandingkan dengan soal UN dimana soal UN (14\%) dan soal UAS SMAN 18 Medan (43\%) hal tersebut menjadi alasan bahwa siswa lebih mampu menjawab soal UN dibandingkan dengan soal UAS Ganjil yang berasal dari SMAN 18 Medan karena soal UAS SMAN 18 lebih sulit dibandingkan dengan soal UN.

\section{Analisis Butir Soal UN dan UAS Ganjil}


JURNAL PELITA PENDIDIKAN VOL. 5 NO. 3

Lubis, SS., Syarifuddin., Dongoran, H.

Halaman : $318-325$

\section{Aspek Kognitif Berdasarkan Taksonomi Bloom}

Hasil penelitian pengelompokan soal berdasarkan ranah kognitif Taksonomi Bloom Soal UAS Ganjil T.P 2016/2017 belum memenuhi proporsi soal yang seimbang. Soal UAS MAN 1 Medan didominasi oleh tingkat kognitif C2 (memahami) $40 \%$, untuk tingkat C1 (mengingat) 32\%, tingkat C3 (mengaplikasikan) dan C4 (menganalisis) masingmasing 24\% dan sisanya C5 (mengevaluasi) dan C6 (menciptakan) tidak tersentuh sedikit pun. UAS MAN 2 Model Medan didominasi oleh tingkat kognitif C2 (memahami) 50\%, untuk tingkat C1 (mengingat) 37\% dan sisanya C3 (mengaplikasikan) 3\%, C4 (menganalisis) 10\%, C5 (mengevaluasi) dan C6 (menciptakan) tidak tersentuh sedikit pun. UAS SMAN 4 Medan didominasi oleh tingkat kognitif C2 (memahami) 46\%, untuk tingkat C1 (mengingat) 26\% dan sisanya C3 (mengaplikasikan) 20\%, C4 (menganalisis) 8\%, C5 (mengevaluasi) dan C6 (menciptakan) tidak tersentuh sedikit pun. UAS SMAN 9 Medan didominasi oleh tingkat kognitif C1 (mengingat) 45\%, untuk tingkat C2 (memahami) 25\% dan sisanya C3 (mengaplikasikan) 20\%, C4 (menganalisis) 5\%, C5 (mengevaluasi) 5\%, dan C6 (menciptakan) tidak tersentuh sedikit pun. UAS SMAN 11 Medan didominasi oleh tingkat kognitif C1 (mengingat) 46\%, untuk tingkat C2 (memahami) 26\% dan sisanya C3 (mengaplikasikan) 23\%, C4 (menganalisis) 5\%, C5 (mengevaluasi) dan C6 (menciptakan) tidak tersentuh sedikit pun. UAS SMAN 18 Medan didominasi oleh tingkat kognitif C2 (memahami) 49\%, untuk tingkat C1 (mengingat) 31\% dan sisanya C3 (mengaplikasikan) 11\%, C4 (menganalisis) 9\%, C5 (mengevaluasi) dan C6 (menciptakan) tidak tersentuh sedikit pun.

Berdasarkan persentase ranah kognitif taksonomi Bloom pada Soal UAS Ganjil T.P 2016/2017 yang telah dianalisis belum memenuhi proporsi soal yang seimbang. Menurut Haryati (2009) apabila bahan ajar telah diajarkan secara lengkap sesuai dengan program yang telah ditetapkan maka membuat alat penilaian (soal) dengan formulasi perbandingan C1 40\%, C2 20\%, C3 20\%, C4 10\%, C5 5\% dan C6 5\%. Namun jika dilihat dari rata-rata persentase setiap ranah belum sesuai dengan persentase teori. Hal ini dapat disebabkan dalam menyusun soal masih mengandalkan kumpulan bank soal-soal atau kumpulan soal dari berbagai buku cetak sehingga untuk penyesuaian ranah kognitif berdasarkan Taksonomi Bloom
pISSN : 2338 - 3003

elSSN : 2502 - 3217 terabaikan, selain itu keterbatasan waktu yang dimiliki oleh pendidik sehingga memaksa pendidik untuk menyusun alat evaluasi berdasarkan kumpulan bank soal.

Tes merupakan salah satu alat evaluasi yang diberikan oleh pendidik kepada siswa. Menurut Sukardi (2008) salah satu tujuan evaluasi adalah untuk mengukur macam-macam aspek belajar yang bervariasi, belajar dikategorikan aspek kognitif, psikomotor, dan afektif. Dalam mengukur aspek kognitif khususnya berdasarkan Taksonomi Bloom harus memperhatikan semua tingkatan aspek agar menghasilkan tes yang baik dan efektif dalam mengevaluasi siswa.

\section{Tingkat Kesukaran Soal UN dan UAS}

Berdasarkan hasil analisis kuantitatif diketahui bahwa soal UN didominasi oleh soal kategori sedang dengan persentase soal sukar $14 \%$ sedang $82 \%$ dan mudah $4 \%$. Dengan demikian sebaran soal UN belum memenuhi proporsi tingkat kesukaran soal yang seimbang, soal yang baik memiliki proporsi tingkat kesukaran dengan persentase $25 \%$ sukar $50 \%$ sedang dan $25 \%$ mudah.

Jika dilihat dari hasil sebaran kriteria tingkat kesukaran soal UAS Ganjil T.P 2016/2017 dari 6 sekolah belum memenuhi proporsi tingkat kesukaran soal yang seimbang, soal yang baik memiliki proporsi tingkat kesukaran dengan persentase $25 \%$ sukar $50 \%$ sedang dan $25 \%$ mudah. Soal UAS Ganjil MAN 1 Medan menunjukkan bahwa hampir dari separuh butir soal yang menyusun tes berada pada kategori tingkat kesukaran mudah (48\%), sebagian soal sisanya ada yang berada pada kategori mudah (36\%), dan yang terendah (16\%) berada pada kategori sukar. Soal UAS Ganjil MAN 2 Model Medan menunjukkan bahwa lebih dari separuh butir soal yang menyusun tes berada pada kategori tingkat kesukaran sedang (53\%). Sebagian soal sisanya ada yang berada pada kategori mudah (33\%), dan yang terendah (14\%) berada pada kategori sukar. Soal UAS Ganjil SMAN 4 Medan menunjukkan bahwa lebih dari separuh butir soal yang menyusun tes berada pada kategori tingkat kesukaran sedang (54\%). Sebagian soal sisanya ada yang berada pada kategori mudah (32\%), dan yang terendah (14\%) berada pada kategori sukar. Soal UAS Ganjil SMAN 9 Medan menunjukkan bahwa lebih dari separuh butir soal yang menyusun tes berada pada kategori tingkat kesukaran mudah (65\%). Sebagian soal sisanya ada yang berada pada 
JURNAL PELITA PENDIDIKAN VOL. 5 NO. 3

Lubis, SS., Syarifuddin., Dongoran, H.

Halaman : $318-325$

kategori sukar (20\%) dan yang terendah (15\%) berada pada kategori sedang. Soal UAS Ganjil SMAN 11 Medan menunjukkan bahwa lebih dari separuh butir soal yang menyusun tes berada pada kategori tingkat kesukaran sedang (69\%). Sebagian soal sisanya ada yang berada pada kategori sukar (20\%), dan yang terendah (11\%) berada pada kategori mudah. Soal UAS Ganjil SMAN 18 Medan menunjukkan bahwa soal yang tergolong sukar dan sedang. memiliki persentase hampir seimbang yaitu soal yang tergolong sukar (43\%) dan soal yang tergolong mudah (46\%), sebagian soal sisanya berada pada kategori mudah (11\%). Jadi perlu dilakukannya perbaikan untuk menghasilkan soal dengan proporsi tingkat kesukaran yang seimbang.

\section{Daya Pembeda Soal UN dan UAS}

Menurut Nasir (2015) kriteria soal yang baik berdasarkan daya pembeda soal adalah apabila kriteria daya pembeda $0,30-1,00 \geq 85 \%$ maka soal dikategorikan baik, dan apabila kriteria daya pembeda $0,30-1,00<85 \%$ maka soal dikategorikan tidak baik. Berdasarkan hasil analisis kuantitatif pada soal UN dan UAS Ganjil T.P 2016/2017 belum memenuhi kriteria daya pembeda soal yang baik. Daya pembeda soal kategori $0,3-1,00$ pada soal UN terdapat 7 butir soal $(4,6,9,14,16,21,22)$ dengan persentase $32 \%$ dengan demikian belum memenuhi kriteria soal yang baik.

Begitu pula pada soal UAS Ganjil T.P 2016/2017 dari setiap sekolah, hasil daya pembeda soal kategori 0,30-1,00 pada soal UAS Ganjil MAN 1 Medan terdapat 9 butir soal $(2,9,11,12,13,15,21,24,25)$ dengan persentase $36 \%$ dengan demikian belum memenuhi kriteria soal yang baik. Selanjutnya soal UAS Ganjil MAN 2 Model Medan terdapat 16 butir soal $(2,4,5,6,7,9,10,12,13,16,17,22,23,26,27$, 30) dengan persentase $53 \%$ dengan demikian belum memenuhi kriteria soal yang baik. Selanjutnya soal SMAN 4 Medan terdapat 18 butir soal $(6,7,8,9,11$, $15,16,17,18,19,20,21,25,27,29,31,32,35)$ dengan persentase $51 \%$ dengan demikian belum memenuhi kriteria soal yang baik. Selanjutnya soal UAS Ganjil SMAN 9 Medan terdapat 7 butir soal (1, $10,11,13,16,17,19)$ dengan persentase $35 \%$ dengan demikian belum memenuhi kriteria soal yang baik. Selanjutnya soal UAS Ganjil SMAN 11 Medan terdapat 17 butir soal $(3,6,9,11,12,15,16,21,22$, $23,24,27,28,30,31,32,34)$ dengan persentase $49 \%$ dengan demikian belum memenuhi kriteria soal yang baik. Selanjutnya soal UAS Ganjil SMAN 18
pISSN : $2338-3003$

elSSN : 2502 - 3217

Medan terdapat 8 butir soal $(6,7,8,10,11,13,14$, 33 ) dengan persentase $23 \%$ dengan demikian belum memenuhi kriteria soal yang baik.

Jadi semua jenis soal perlu dilakukannya perbaikan untuk lebih menghasilkan soal dengan kriteria sebaran daya pembeda yang lebih baik yaitu dengan kriteria daya pembeda 0,30-1,00 $\geq 85 \%$. Khususnya pada soal-soal yang daya pembedanya tergolong jelek dan cukup perlu dilakukannya revisi agar dapat digunakan kembali dalam evaluasi hasil belajar, sedangkan soal-soal yang memiliki nilai negative sebaiknya tidak digunakan lagi karena kualitas butir soalnya sangat jelek.

\section{Reliabilitas Soal UN dan Semester Ganjil}

Indeks reliabilitas berkisar antara 0-1 dengan lima kriteria. Semakin tinggi koefisien reliabilitas suatu tes, semakin tinggi pula keajegan atau ketepatannya. Hasil analisis menunjukkan Soal UN memiliki indeks reliabilitas sebesar 0,3, berdasarkan kriteria yang digunakan indeks reliabilitas termasuk rendah. Pada Soal UAS Ganjil MAN 1 Medan memiliki indeks reliabilitas sebesar 0,72 , berdasarkan kriteria yang digunakan indeks reliabilitas termasuk kategori tinggi, soal UAS Ganjil MAN 2 Model Medan memiliki indeks reliabilitas sebesar 0,78, berdasarkan kriteria yang digunakan indeks reliabilitas termasuk kategori tinggi, soal UAS Ganjil SMAN 4 Medan memiliki indeks reliabilitas sebesar 0,89, berdasarkan kriteria yang digunakan indeks reliabilitas termasuk kategori sangat reliabel, soal UAS Ganjil SMAN 9 Medan memiliki indeks reliabilitas sebesar 0,56 , berdasarkan kriteria yang digunakan indeks reliabilitas termasuk kategori sedang, soal UAS Ganjil SMAN 11 Medan memiliki indeks reliabilitas sebesar 0,8 , berdasarkan kriteria yang digunakan indeks reliabilitas termasuk kategori tinggi, soal UAS Ganjil SMAN 18 Medan memiliki indeks reliabilitas sebesar 0,53 , berdasarkan kriteria yang digunakan indeks reliabilitas termasuk kategori sedang.

\section{KESIMPULAN}

Berdasarkan nilai rata-rata siswa lebih mampu menjawab soal UAS Ganjil T.P 2016/2017 dibandingkan dengan soal UN khususnya soal UAS yang berasal dari MAN 1 Medan, MAN 2 Model Medan, SMAN 4 Medan, SMAN 9 Medan dan SMAN 11 Medan. Hasil analisis persentase aspek kognitif Taksonomi Bloom pada soal UAS Ganjil MAN 1 Medan, MAN 2 Model Medan, SMAN 4 Medan, SMAN 11 dan SMAN 18 Medan belum sesuai dengan 
JURNAL PELITA PENDIDIKAN VOL. 5 NO. 3

Lubis, SS., Syarifuddin., Dongoran, $\mathrm{H}$.

Halaman : $318-325$

teori yaitu dengan formulasi perbandingan C1 (40\%), C2 (20\%), C3 (20\%), C4 (10\%), C5 (5\%) dan C6 (5\%). Berdasarkan analisis kuantitatif pada butir soal UN materi kelas XI Semester Ganjil Tahun 2012 - 2016 dan Soal UAS Ganjil T.P 2016/2017 soal belum memenuhi kriteria soal yang baik.

\section{UCAPAN TERIMAKASIH}

Kepada Bapak H. Ali Masran Daulay selaku Kepala Sekolah MAN 1 Medan yang telah memberikan izin untuk melakukan penelitian kepada penulis serta guru bidang studi Biologi Ibu Herawati dan Ibu Puspa yang telah memberikan bimbingan dan bekerjasama dalam penelitian ini.

\section{DAFTAR PUSTAKA}

Arifin, Z., (2009), Evaluasi Pembelajaran, PT Remaja Rosdakarya, Bandung

Arikunto, S., (2013), Dasar Dasar Evaluasi Pendidikan, Bumi Aksara, Jakarta

BSNP, (2017), Prosedur Operasional Standar Penyelenggaraan Ujian Nasional, Jakarta

Daryanto, H., (2008), Evaluasi Pendidikan, Rineka Cipta, Jakarta

Dira, M., (2013), Analisis Soal Ulangan Akhir Semester UAS Biologi SMA Kelas X Ditinjau dari Taksonomi Bloom Studi Kasus Pada 9 SMAN Kota Bogor, Skripsi, Universitas Islam Negeri Syarif Hidayatullah, Jakarta

Djaali, H., dan Muljono, P., (2008), Pengukuran dalam Bidang Pendidikan, PT Grasindo, Jakarta

Fathurrohman, P., dan Sutikno, S., (2007), Strategi Belajar Mengajar, PT Refika Aditama, Bandung

Haryati, M., (2007), Model dan Teknik Penilaian Tingkat Satuan Pendidikan, GP Press, Jakarta

Indrawati, S.N., (2015), Analisis Butir Soal Ujian Akhir Semester Gasal Mata Pelajaran Pengantar Akuntansi Dan Keuangan Kelas X Akuntansi Di Smk Negeri 1 Tempel Tahun Ajaran
pISSN : 2338 - 3003

elSSN : 2502 - 3217

2014/2015, Skripsi, Universitas Negeri Yogyakarta, Yogyakarta

Masruroh., R.E., dan Ridlo, S., (2012), Analisis Soal Ulangan Semester Gasal Biologi Kelas X Di Kecamatan Petanahan Kebumen, Journal of Biology Education, 12: 116-121

Nasir, M., (2015), Analisis Empirik Program Analisis Butir Soal Dalam Rangka Menghasilkan Soal Yang Baik Dan Bermutu Sebagai Alat Evaluasi Pembelajaran Fisika, Prosiding Semirata 2015 bidang MIPA BKS-PTN Barat, 336-347

Purwanto, M.N., (2009), Prinsip-Prinsip dan Teknik Evaluasi Pengajaran, PT Remaja Rosdakarya, Bandung

Rusyna, A., (2014), Keterampilan Berfikir, Yogyakarta, Ombak

Sukardi, H.M., (2008), Evaluasi Pendidikan Prinsip \& Operasionalnya, Bumi Aksara, Jakarta

Suprananto, K., (2012), Pengukuran dan Penilaian Pendidikan, Graha Ilmu, Yogyakarta

Surapranata, S., (2005), Analisis Validitas Reliabilitas Interpretasi Hasil Tes, PT Remaja Rosdakarya, Bandung

Susetyo, B., (2015), Prosedur Penyusunan \& Analisis Tes, PT Refika Aditama, Bandung 